\title{
Polymyalgia rheumatica update, 2015
}

\author{
Schmidt Zsuzsa dr. - Poór Gyula dr.
}

Országos Reumatológiai és Fizioterápiás Intézet, Budapest

\begin{abstract}
A polymyalgia rheumatica az 50 év feletti korosztály gyulladásos mozgásszervi megbetegedése, amelyet a vállak, csípók, nyak kifejezett fájdalma, reggeli merevsége és nagy szisztémás gyulladás jellemez, rendszerint jól és gyorsan reagál kis dózisú glükokortikoidra. Óriássejtes arteritissel való társulása régóta ismert. Az utóbbi évek klinikai megfigyelései és tudományos eredményei újabb kihívásokat állítottak a reumatológusszakma elé. Az aspecifikus, de jellegzetes polymyalgiás szindróma mellett változatos perifériás ízületi tüneteket figyeltek meg. A mozgásszervi tünetek hátterében mágneses rezonanciás és ultrahangvizsgálatokkal enyhe, múló, eróziót nem okozó synovitist igazoltak, amely döntően extraartikuláris megjelenésü. Mivel potognosztikus tünete nincs, a PMR diagnózisa továbbra is a differenciáldiagnosztikailag szóba jövő betegségektől való elkülönítésen alapul. Különösen nehéz az időskori gyulladásos arthritisek, időskori rheumatoid arthritis, késői kezdetű spondylarthritis elkülönítése. 2012-ben az amerikai (ACR) és az európai (EULAR) reumatársaságok polymyalgia rheumatica munkacsoportja klasszifikációs kritériumokat hozott létre, amelynek pontozásos algoritmusa szintén a klinikai tünetekre épül, az ultrahang-kritériumok további segítséget jelentenek. A polymyalgia rheumatica terápiája változatlanul a kis dózisú glükokortikoid, azt helyettesítő hatásos gyógyszer ez ideig nem ismert. A glükokortikoidterápia általában 1-1,5 éven belül elhagyható, az esetek egy részében azonban relapsusokkal járó krónikus lefolyás figyelhető meg, a glükokortikoidok hosszú távú, éveken át tartó adása szükséges. A glükokortikoidok jól ismert mellékhatásai (diabetes, hypertonia, hyperlipidaemia, osteoporosis) jelentős morbiditást, gazdasági terhet jelentenek. Újabb gyógyszervizsgálatok folyamatban vannak. A betegség korai felismerése, a glükokortikoidterápia mielőbbi elkezdése és szabályos kivitelezése, a mellékhatások megelőzése és kezelése a reumatológusok mellett a családorvosok napi feladata. A polymyalgia rheumatica ismerete az összes orvosi szakma számára nélkülözhetetlen. Orv. Hetil., 2016, 157(1), 2-12.
\end{abstract}

Kulcsszavak: polymyalgia rheumatica, glükokortikoidok, óriássejtes arteritis

\section{Polymyalgia rheumatica update, 2015}

Polymyalgia rheumatica is an inflammatory musculoskeletal disorder of people aged 50 years or over, characterised by pain, aching and morning stiffness in the shoulder girdle and often hip girdle and neck. Marked systemic inflammation and rapid response to corticosteroid therapy are characteristic features. Giant cell arteritis is a well-known association of polymyalgia rheumatica. Recent clinical evidence and scientific results in the field have provided new challenges for rheumatologists. Besides the aspecific - although characteristic - proximal syndrome, less well recognizable and more variable distal musculoskeletal manifestations were observed. Magnetic resonance and ultrasound studies showed mild, remitting and non-erosive synovitis, with dominating inflammation of the extraarticular synovial structures. As no pathognostic sign is known, the diagnosis of polymyalgia rheumatica is based on its differential diagnosis, differentiation from the polymyalgia mimics; particularly from elderly onset inflammatory arthritides, such as elderly onset rheumatoid arthritis and late onset seronegative spondylarthritis. In 2012 the international polymyalgia rheumatica work group under the guidance of the American College of Rheumatology and European League Against Rheumatism elaborated new classification criteria, the scoring algorythm of which is based on clinical symptoms, with ultrasonography increasing the specificity. Corticosteroids remain the cornerstone of the therapy of polymyalgia rheumatica. No effective steroid-sparing drug has been found to date. Corticosteroids are generally needed for $1-1.5$ years, though some patients have a chronic-relapsing course and require corticosteroids for several years. Well known corticosteroid-related side effects (diabetes, hypertension, hyperlipidaemia and osteoporosis) cause significant morbidity and economic burden on the society. Novel therapeautic approaches are on trial. Early recognition of the disease, early start of corticosteroids and a well-defined course, prevention and management of side effects are everyday tasks for rheumatologists and family doctors. Knowledge of polymyalgia rheumatica is essential for all medical specialties.

Keywords: polymyalgia rheumatica, glucocorticoids, giant cell arteritis

Schmidt, Zs., Poór, Gy. [Polymyalgia rheumatica update, 2015]. Orv. Hetil., 2016, 157(1), 2-12.

(Beérkezett: 2015. október 1.; elfogadva: 2015. október 29.) 


\section{Rövidítések}

aCCP = anticiklikus citrullinált fehérje elleni antitest; $\mathrm{aCl}=$ antikardiolipin-antitest; ACR = American College of Rheumatology; ANCA = antineutrophil citoplazmatikus antitest; $\mathrm{ANF}=$ antinukleáris faktor; $\mathrm{CK}=$ kreatinkináz; $\mathrm{CRP}=\mathrm{C}$-reaktív protein; $\mathrm{CT}=$ komputertomográfia; $\mathrm{DM}-\mathrm{PM}=$ dermatomyositispolymyositis; DMARD = betegségmódosító szer; EORA = időskorban kezdődő rheumatoid arthritis; EULAR = European League Against Rheumatism; FDG-PET = fluoro-18-deoxiglükóz-pozitronemissziós tomográfia; $\mathrm{FUO}=$ ismeretlen eredetû láz; GC = glükokortikoid; GC-rezisztens PMR = a krónikus, relapsusokkal járó PMR szinonim elnevezése, amikor a PMR lege artis GC-terápiára teljesen nem gyógyul, a GC el nem hagyható; GCA = óriássejtes arteritis; HLA = humán leukocyta-antigén; HPA-tengely = hypothalamus-hypophysismellékvese tengely; ICAM-1 = intracelluláris adhéziós molekula; IL-1, IL-6 = interleukin-1, -6; IL-1Ra = interleukin-1 receptorantagonista; INF- $\gamma=$ interferon $-\gamma$; izolált PMR $=$ PMR óriássejtes arteritis klinikai tünetei nélkül; kis dózisú $\mathrm{GC}=$ hagyományosan kis dózisú GC-nek nevezzük a 15-20 mg/nap GC-t, a GCA-ban szükséges nagy dózisú GC (40-60 mg/nap) viszonylatában; LO-SpA = késői kezdetû spondylarthritis; $\mathrm{MR}$ $=$ mágneses rezonancia MTX $=$ methotrexat PED = prednizolonekvivalens dózis; $\mathrm{PET}=$ pozitronemissziós tomográfia; PMR = polymyalgia rheumatica; PMR-AS $=$ PMR-aktivitási score; PsA = arthritis /spondylarthritis psoriatica; $\mathrm{PTH}=$ parathormon; RA = rheumatoid arthritis; RCT $=$ randomizált kont rollált vizsgálat; $\mathrm{RF}=$ rheumatoid faktor; $\mathrm{RIM}=$ reggeli ízületi merevség; RS3PE = múló szeronegatív szimmetrikus synovitis ujjbenyomatot tartó oedemával; sIL-6R = szolúbilis interleukin-6 receptor; SLE = szisztémás lupus erythematosus; SpA (régi nevén SNSA) = nem differenciált spondylarthritis; SPA = spondylarthritis ankylopoetica; TA = temporalis arteritis, temporalis artéria; $\mathrm{TAB}=$ temporalisartéria-biopszia; TNF- $\alpha=$ tumornekrózis-faktor- $\alpha$; TSH = thyreoideastimuláló hormon; $\mathrm{UH}=$ ultrahang; VAS = vizuális analóg skála; We = Westergreen-érték (vörösvértest-süllyedés)

A polymyalgia rheumatica (PMR) az időskorúak leggyakoribb gyulladásos mozgásszervi megbetegedése, a hoszszú távú glükokortikoid- (GC-) terápia leggyakoribb indikációja, annak súlyos gazdasági-társadalmi következményeivel. A nyugati társadalmak elöregedésével és az éves incidencia növekedésével előtérbe kerül e sokszor félreértett betegség ismeretének szükségessége.

A PMR-nek patognosztikus tünete nincs, a diagnózis felállítása a jellegzetes kezdeti tünetek alapján történik. Az utóbbi évek tudományos eredményei, klinikai megfigyelései új kihívásokat állítanak elénk (1. táblázat). A „polymyalgiás” proximális tünetcsoport nem specifikus, egyre gyakrabban distalis mozgásszervi tünetek megjelenését is leírják. A képalkotó diagnosztika fejlődésével a PMR ízületi gyulladásos jellege kap megerősítést, kórjelző autoantitestet kimutatni azonban továbbra sem sikerül. Megdőlni látszik a PMR közismerten jó GC-terápiás válasza is, az esetek egy részében GC-rezisztens lefolyás figyelhető meg, a remisszió fenntartásához a GC hosszú távú adása szükséges. (A GC-rezisztens PMR a krónikus, relapsusokkal járó PMR szinonim elnevezése,
1. táblázat | A PMR kihívásai napjainkban

A proximális tünetcsoport aspecificitása

Arteritis társulása az esetek 16-21\%-ában

Distalis ízületi érintettség a PMR közel 50\%-ában

Szisztémás tünetek hiányozhatnak

PMR normális We-értékkel (7-22\%)

„GC-rezisztens” PMR

amikor a PMR lege artis GC-terápiára teljesen nem gyógyul, a GC el nem hagyható.)

$\mathrm{Az}$ új eredmények bevonásával az amerikai (ACR) és az európai (EULAR) reumatársaságok illetékes munkacsoportja nemzetközileg standardizált és validált kritériumrendszert dolgozott ki, amely nemcsak a PMR klaszszifikációjára és a klinikai gyógyszervizsgálatok alapjául szolgáló homogén betegcsoportok kialakítására alkalmas, hanem a mindennapi gyakorlatban is segítségünkre szolgálhat.

A PMR felismerése, más betegségektől való elkülönítése és kezelése egyaránt nehéz szakorvosi feladat, ismerete azonban a családorvosok és a társszakmák számára is nélkülözhetetlen. Dolgozatunkban ehhez kívánunk segítséget nyújtani.

\section{Definíció}

A PMR az „idős” betegek jellegzetes gyulladásos mozgásszervi megbetegedése, amelyet a jól ismert „polymyalgiás" tünetcsoport (heves vállövi és/vagy medenceövi fájdalom, merevség) és nagy gyulladás jellemez (kifejezett szisztémás tünetekkel, nagyfokú laboratóriumi gyulladással). A polymyalgiához perifériás tünetek társulhatnak, arteritises asszociációja régóta ismert. Rendszerint jól reagál kis dózisú glükokortikoidra [1-5].

\section{Történet}

A PMR múvészi megjelenítései a társuló óriássejtes arteritist ábrázolják, a képeken a halántéktáji artéria feszülő kötegként figyelhetố meg (1. ábra). A van der Paele-i kolostor naplója a kanonok rossz általános és mozgásszervi állapotáról is beszámol, miseszolgálatot képtelen volt teljesíteni hónapokon át (1400-as évek).

A PMR első orvosi esetleírása 1888-ban jelent meg, Bruce mint szenilis reumás köszvényrôl számol be róla. Hosszú szünet után, az 1940-es, 1950-es években sorra jelennek meg különálló közlemények: Az időskorúak myalgiás szindrómája, Az időskor arthritise, Anarthritises rheumatoid szindróma címmel - a különböző elnevezések a megmagyarázhatatlan polymyalgiás kórkép heterogenitására utalnak. A ma is használatos polymyalgia rheumatica elnevezés H.S. Barbertöl származik, a Myalgiás szindróma általános tünetekkel címú közleményében használja (1957). 


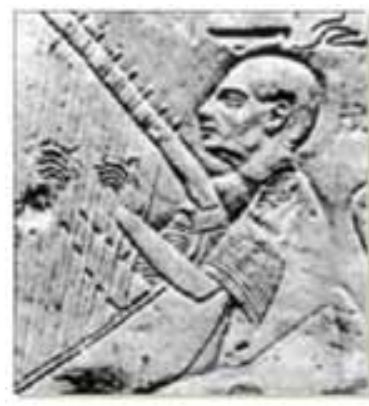

a)

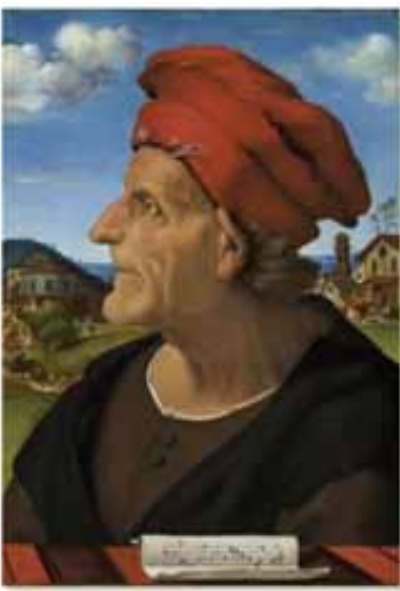

b)

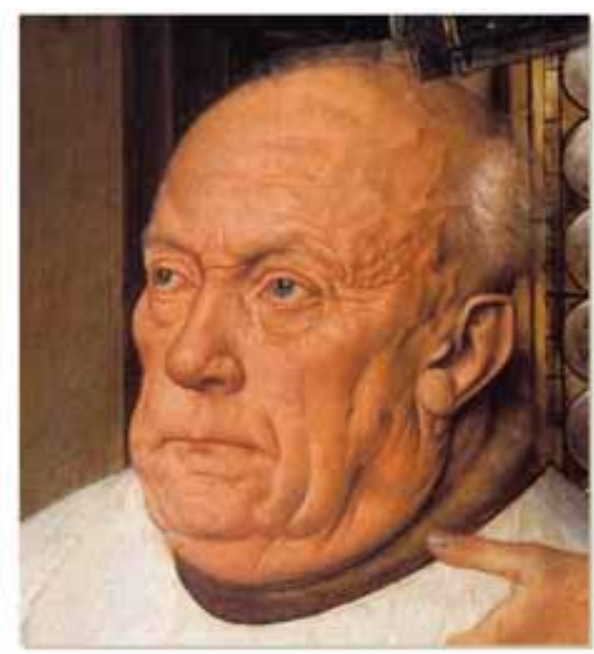

c)

\begin{tabular}{l|l} 
1. ábra & $\begin{array}{l}\text { A polymyalgia rheumatica (+temporalis arteritis) múvészi ábrázolásai } \\
\text { a) A vak hárfás, i. e. 1300, amarnai sírkamra } \\
\text { b) Piero di Cosimo. Francesco Giamberti portréja (1482), Amszterdam } \\
\text { c) Van der Paele-i kanonok. Jan van Eyck (1436), Bruges }\end{array}$
\end{tabular}

A PMR és az óriássejtes arteritis (GCA) kapcsolatát először skandináv szerző́k vetik fel (Polymyalgia arteritica, 1968). L. A. Healey a PMR és az időskorban kezdődó RA (EORA) közös jellegzetességeire mutat rá (1984). A Mayo Klinikán már az 1950-es évektől intenzív kutatómunka folyik PMR/GCA témában, jól ismert $G$. $G$. Hunder munkássága [6]. Az 1970-es éveket elérve a két betegség klinikai rokonságához nem fér kétség (1978ban magyar közlemény is megjelent e témában) [7], az azonban, hogy a PMR patogenetikai folyamata proximális synovitis vagy vasculitis, továbbra is vitatott maradt.

A PMR-t ma synovialis megbetegedésnek tartjuk. Ennek igazolása C. Salvarani és munkacsoportja érdeme, úttörő munkásságuk mindenképpen kiemelendő (1990es évektől), nevükhöz füződik a proximális gyulladás extraarticularis észrevétele, a társuló distalis ízületi megjelenés, de a GC-rezisztenciára való felfigyelés is [1]. Napjainkban szakértőkből nemzetközi munkacsoport alakult, az ACR részéról E. Matteson (Mayo Klinika), az EULAR részéről B. Dasgupta (UK - Southend Univ.) vezetésével aktív kollaborációs munka folyik a betegséggel kapcsolatos diagnosztikus, terápiás kérdések közös megválaszolására, standardizálására és az ezzel kapcsolatos kutatómunka elősegítésére [8].

\section{Epidemiológia}

A PMR átlagos prevalenciáját, incidenciáját a GCA, az EORA és az RA viszonylatában tüntettük fel (2. táblá$z a t)$. Angliában az incidencia $8,4 / 10000$ betegév, a prevalencia $739 / 100000(0,7 \%)[1,9,10]$.
A PMR az 50 év feletti korosztály megbetegedése, 50 év felett átlagosan minden 133. embernek van vagy volt polymyalgiája. Az incidencia az életkor előrehaladtával nő, 70-80 éves korban a legmagasabb. Minden korcsoportban nôknél gyakoribb, bár a nemi arány kiegyenlítettebb (2-3:1). Előfordulásában jelentős regionálisetnikai különbségek figyelhetők meg, az Egyenlítőtől északra: Skandináviában, a Brit-szigeteken és ÉszakAmerikában gyakori, az angolszászok-északiak betegsége, többnyire skandináv (viking) eredettel. Az arteritis társulása is különböző, a mediterrán országokra az izolált forma (GCA társulása nélküli PMR) előfordulása jellemző. Napjainkban az incidencia növekvő tendenciát mutat $[1,9,10]$.

A PMR-betegek egészségügyi ellátása jelentős gazdasági terhet ró a társadalomra, amely döntően a cardiovascularis társbetegségek egészségügyi ellátását, a kórházi ápolási napok és a modern képalkotás költségeit jelenti. A PMR-beteg ischaemiás érbetegségekkel (szívinfarktus, perifériás érbetegség, cerebrovascularis betegség) szembeni rizikója kortársaihoz képest magasabb [10].

2. táblázat | PMR-incidencia, -prevalencia

\begin{tabular}{lcc}
\hline & $\begin{array}{c}\text { l éves incidencia } \\
/ 100000 \text { lakos }\end{array}$ & Prevalencia \\
\hline PMR $>50$ éves & $20-50$ & $0,6 \%$ \\
GCA $>50$ éves & $4-20$ & $0,12 \%$ \\
EORA $>60$ éves & 60 & $0,14 \%$ \\
RA & & $0,5 \%$ \\
\hline
\end{tabular}




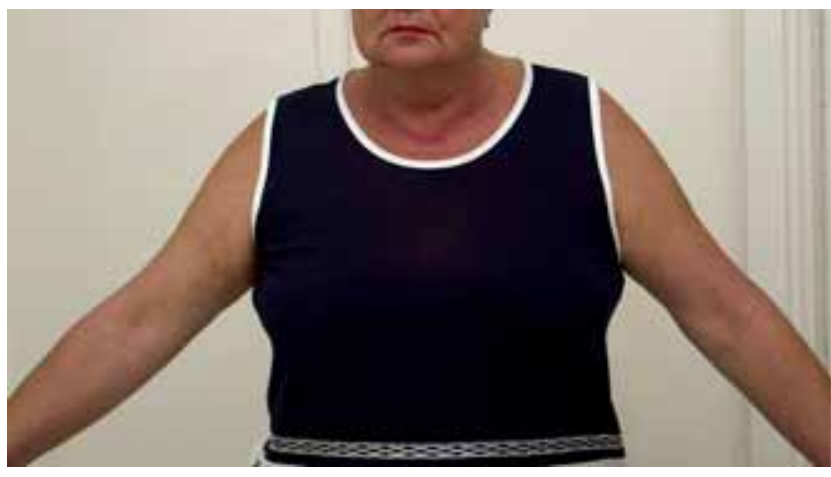

2. ábra $\quad$ A PMR-re jellegzetes proximális tünetcsoport

\section{Etiopatogenezis}

A PMR ismeretlen etiológiájú, multifaktoriális kórkép, genetikai fogékonyság mellett környezeti faktorok játszanak szerepet a kiváltásában.

Genetikai asszociációja többek között az RA HLA-DR asszociációival $\left(\mathrm{DRBI}{ }^{*} 01,04\right)$ egyező, de az asszociációk erőssége lényegesen gyengébb, és ez is regionálisetnikai különbségeket mutat [11]. A DR-asszociációk a PMR-fogékonyság mellett a betegség súlyosságával is összefüggnek. Saját vizsgálatunkban magyar populáción a DRB1*0401 szubtípus asszociációját szignifikánsan alacsonyabbnak találtuk PMR-ben, mint RA-ban [12, 13]. Ugyanakkor spanyolok a DRBI*0401 szubtípus súlyos, relapsusokkal járó PMR-rel való asszociációját írták le. További gyulladásos gének (ICAM-1, TNF,
RANTES, IL-1 Ra) polimorfizmusát is vizsgálták, az ICAM-1-asszociáció szintén súlyos lefolyást, fokozott relapsuskockázatot jelent izolált PMR-ben [4].

A PMR-incidencia és bizonyos járványok parallel változása, a ciklikus-szezonális minta a környezeti faktorok, fertőző etiológia szerepét vetik fel (Mycoplasma pneumoniae, Chlamydia pneumoniae, parvovírus B19, parainfluenza l).

Bár a szisztémás autoimmun betegségek közé soroljuk, ez ideig izolált PMR-ben keringő autoantitestet nem sikerült kimutatni. Megelőző vírus-, esetleg bakteriális infekciók, vakcinák [14] a fogékony szervezetben szisztémás monocyta-macrophag aktivációt váltanak ki, a nagyszámú proinflammatorikus citokin (TNF- $\alpha$, IL-1, IL-6) eredménye a nagyfokú szisztémás gyulladás [15]. Az aktív PMR-t leginkább az IL-6 túltermelése jellemzi, perzisztálóan magas IL-6-szint a krónikus/relapsusokkal járó, úgynevezett GC-rezisztens PMR jele [16]. A PMR szisztémás aspecifikus gyulladása később lokális adaptív immunválaszba mehet át, a váll synovialis membránjában macrophagok mellett domináló CD4+ T-lymphocytákat találtak, míg társuló temporalis arteritis kialakulásához gamma-interferon- (INF- $\left.\gamma^{-}\right)$termelés szükséges [4].

A folyamat kiváltásában az immun- és az endokrin rendszer öregedése (immuno-endocrinosenescence) és a krónikus stressz, a hypothalamus-hypophysis-mellékvese (HPA) tengely kimerülése feltétlenül szerepet játszik [17].
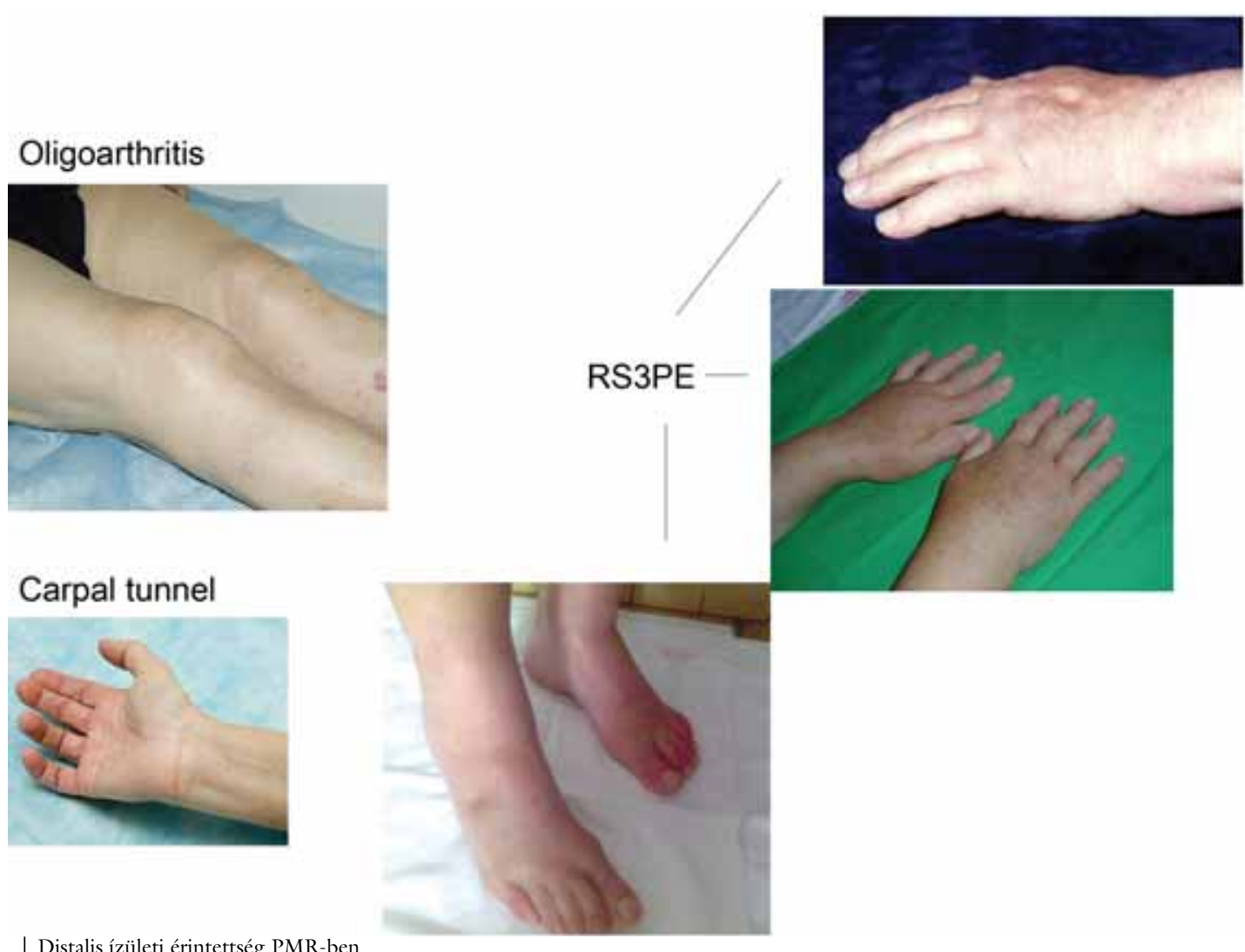

3. ábra

| Distalis ízületi érintettség PMR-ben 


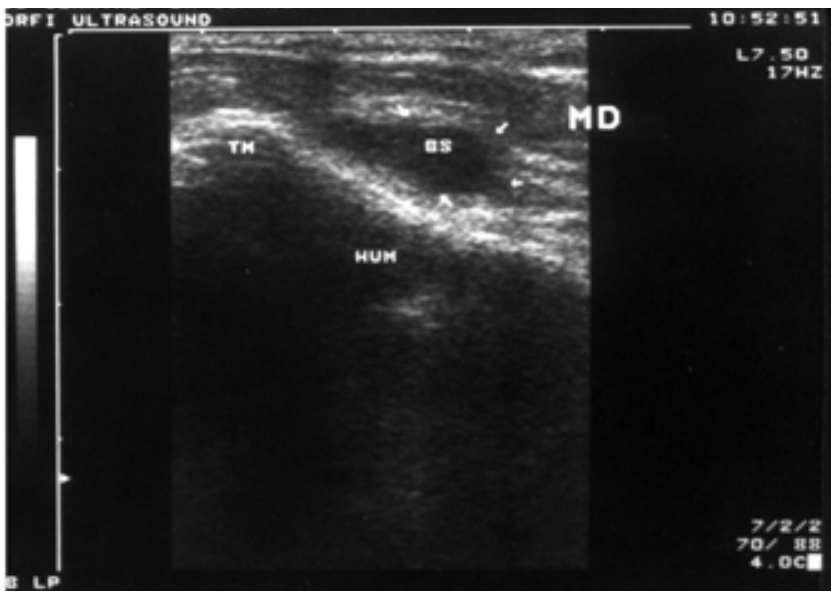

4. ábra

A subacromialis bursitis UH-képe

(váll, ferde coronalis sík)

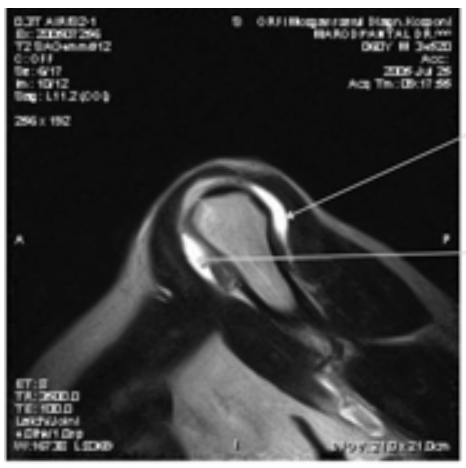

Subacromialis bursitis

Biceps tenosynovitis

T2w sagittal

5. ábra $\quad$ A bursitis, tenosynovitis MR-képe.

T2-súlyozott ferde sagittalis metszet

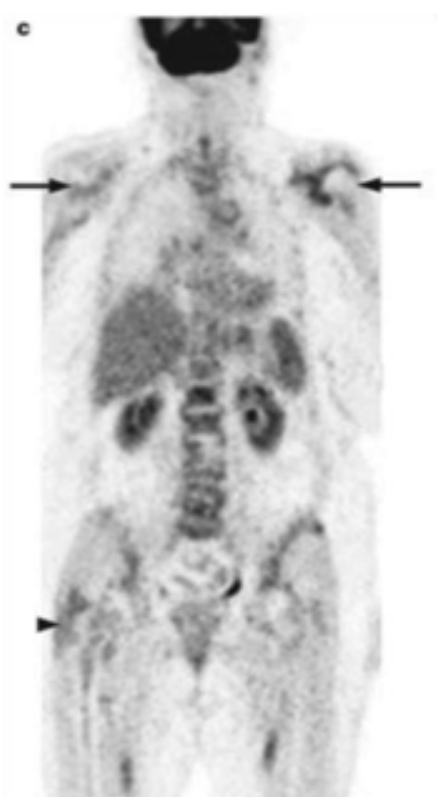

d

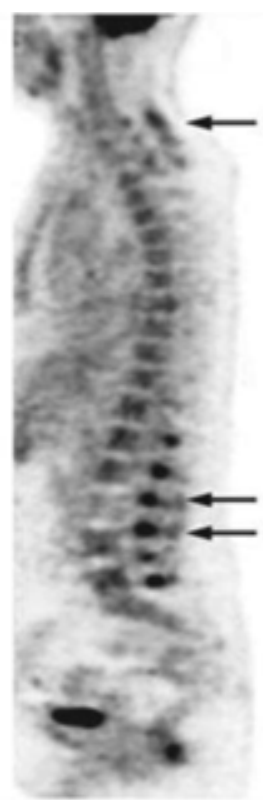

6. ábra

FDG/PET PMR-ben:

gyulladásos FDG-halmozás a váll, a csípó és a gerinc területén

\section{Klinikum}

PMR-re akkor gondolunk, ha az „idős”, 50 év feletti beteg heves kétoldali váll-, esetenként csípőfájdalmat panaszol hosszan tartó reggeli merevséggel, és rendszerint általános tünetei (láz, fáradékonyság, elesettség, fogyás) is vannak. A fájdalom izomlázszerü, mozgásra fokozódik, aktív és sokszor passzív mozgáskorlátozottsággal jár, a szokványos napi tevékenységet akadályozza, sőt olyan erős is lehet, hogy a beteg ágyba kényszerül. A panaszok súlyosak, fizikális vizsgálatkor azonban szerény tüneteket találunk, a felkar izomzata nyomásérzékeny. Ez az a bizonyos proximális tünetcsoport (2. ábra), amely a PMRre olyan jellegzetes, de nem specifikus. Újabban perifériás ízületi gyulladást, arthritist, tenosynovitist, sőt az időskori mozgásszervi megbetegedésekhez egyébként is gyakran társuló RS3PE-szindrómát (múló szeronegatív szimmetrikus synovitis ujjbenyomatot tartó duzzanattal) is megfigyeltek már PMR-ben, a carpal tunnel szindróma pedig közel egyforma gyakorisággal fordul elő, mint RAban. Perifériás tünetek az esetek közel felében (39-45\%) társulnak, ezek még kevésbé ismertek és sokkal változatosabbak, mint a proximális tünetcsoport (3. ábra). A polymyalgiás synovitis olyan enyhe és átmeneti, hogy a vizsgáló könnyen észre sem veszi, ha nem figyel rá, a vállízületi duzzanat szinte észlelhetetlen [4, 8, 18-20].

A betegség döntő többségében (70-95\%) vállérintettséggel kezdődik, csak csípőérintettséggel induláskor az esetek 5\%-ában számolhatunk. A perifériás érintettség leggyakrabban oligoarthritis, a csukló és/vagy a térd részvételével.

A polymyalgiás betegek ötödében (16-21\%) a mozgásszervi tünetek értünetekkel együtt jelentkeznek, társuló temporalis arteritisre (TA) utal leggyakrabban a halántéktáji fejfájás és a látászavar. Szembetűnő lehet a feszülő kötegezett halántéktáji artéria, amely tapintáskor érzékeny és pulzációja csökkent.

\section{Diagnosztika}

\section{Képalkotó vizsgálatok}

Tőízületi synovitist szcintigráfiával (fokozott radioaktivitás) már az 1970-es években kimutattak a Mayo Klinikán, 1992-ben a finn J. Koski ultrahang- (UH-) vizsgálattal a PMR-betegek 68\%-ában váll- és/vagy csípősynovitist detektált.

Az utóbbi években a képalkotó diagnosztika fejlődésével, a váll és a csípő UH- és mágneses rezonanciás (MR-) vizsgálatával egyre nyilvánvalóbbá lett, hogy a polymyalgiás tünetek hátterében synovitis áll. Az enyhe, múló és az RA-val ellentétben a röntgenképen erozív elváltozást nem okozó PMR-es synovitis az erős fájdalmakat, nagyfokú kötöttséget azonban nem magyarázza. Salvarani és munkacsoportja igazolta, hogy az ízület mellett az extraarticularis synovialis képletek is érintettek, s ezek synovitise (vállízület esetén subacromiodeltoidealis bursitis, 
3. táblázat |A PMR klasszifikációs/diagnosztikus kritériumai

\begin{tabular}{|c|c|c|c|c|}
\hline & $\begin{array}{l}\text { ACR/ } \\
\text { EULAR } \\
2012\end{array}$ & $\begin{array}{l}\text { Healey/ } \\
\text { Hunder } \\
1984\end{array}$ & $\begin{array}{l}\text { Jones } \\
1981\end{array}$ & $\begin{array}{l}\text { Bird } \\
1979\end{array}$ \\
\hline Életkor & $>50$ éves & $>50$ éves & $>50$ éves & $>65$ éves \\
\hline $\begin{array}{l}\text { Nyak, váll } \\
\text { és csípó } \\
\text { kétoldali } \\
\text { fájdalma }\end{array}$ & $\begin{array}{l}\text { Váll } \\
+/- \text { csípó }\end{array}$ & Bármelyik 2 & $\begin{array}{l}\text { Váll } \\
\text { +csípö }\end{array}$ & Váll \\
\hline $\begin{array}{l}\text { We/CRP } \\
\text { emelkedett }\end{array}$ & Igen & $>40 \mathrm{~mm} / \mathrm{h}$ & $>30 \mathrm{~mm} / \mathrm{h}$ & $>40 \mathrm{~mm} / \mathrm{h}$ \\
\hline $\begin{array}{l}\text { Reggeli } \\
\text { merevség }\end{array}$ & $>45 \mathrm{~min}$ & $>1 \mathrm{~h}$ & $>1 \mathrm{~h}$ & $>1 \mathrm{~h}$ \\
\hline $\begin{array}{l}\text { A tünetek } \\
\text { kezdete }\end{array}$ & & $<2$ hét & & $<2$ hét \\
\hline $\begin{array}{l}\text { A tünetek } \\
\text { időtartama }\end{array}$ & & $>1$ hó & $>2$ hó & \\
\hline $\begin{array}{l}\text { Gyors } \\
\text { GC-válasz* }\end{array}$ & & Igen & Igen & \\
\hline Egyebek & $\begin{array}{l}\text { UH- } \\
\text { kritérium }\end{array}$ & & & $\begin{array}{l}\text { Kétoldali } \\
\text { felkar érz. } \\
\text { depresszió/ } \\
\text { fogyás }\end{array}$ \\
\hline $\begin{array}{l}\text { Egyéb } \\
\text { betegség } \\
\text { kizárása }\end{array}$ & $\begin{array}{l}\text { RA- } \\
\text { szerológia, } \\
\text { distalis } \\
\text { érintettség }\end{array}$ & Igen & $\begin{array}{l}\text { RA, } \\
\text { izom- } \\
\text { betegség }\end{array}$ & $\mathrm{Nem}$ \\
\hline Diagnózis & $\begin{array}{l}3 \text { alap- } \\
\text { kritérium } \\
+4 / 5 \text { pont }\end{array}$ & $\begin{array}{l}\text { Valamennyi } \\
\text { kritérium }\end{array}$ & $\begin{array}{l}\text { Valamennyi } \\
\text { kritérium }\end{array}$ & Bármelyik 3 \\
\hline
\end{tabular}

*PED $<20 \mathrm{mg} /$ die

\section{4. táblázat $\mid$ A PMR ACR/EULAR kritériumai, 2012 \\ - pontozásos algoritmus}

\begin{tabular}{|c|c|c|}
\hline$>50$ éves & Kötelező & \\
\hline $\begin{array}{l}\text { Újonnan kezdődött kétoldali } \\
\text { vállfájdalom }\end{array}$ & Kötelező & \\
\hline Kóros We/CRP & Kötelező & \\
\hline RIM $>45$ perc & 2 & \multirow{6}{*}{$\geq 4$} \\
\hline Csípőfájdalom vagy -kötöttség & 1 & \\
\hline Normális RF/aCCP & 2 & \\
\hline Perifériás ízületi érintettség hiánya & 1 & \\
\hline UH legalább 1 váll BTS* és 1 csípő BS & 1 & \\
\hline UH kétoldali váll-BTS & 1 & \\
\hline
\end{tabular}

${ }^{*} \mathrm{~B}$ bursitis

T tenosynovitis

$\mathrm{S}$ synovitis

biceps tenosynovitis) közösen felelhet a súlyos polymyalgiás panaszokért. Az MR-vizsgálat drága, UH-vizsgálatot egyre többen végeznek. Jellegzetes elváltozásnak tưnik az ultrahanggal kimutatott kétoldali vállbursitis (az esetek 96\%-ában), amelyet az olasz kollégák diagnosztikus kritériumnak is javasoltak, de ez még megerősítésre vár [21-23]. Az ACR/EULAR multicentrikus vizsgálat opcionális UH-ágában vállgyulladást a PMR-betegek 59\%-ában tudtak detektálni, az RA-hoz képest PMR-ben a subacromialis bursitis relatív túlsúlya itt is megfigyelhető [24]. A szakirodalmi adatok legújabb feldolgozása, metaanalízise szintén a PMR-gyulladás jellegzetes extraarticularis megjelenését erôsíti meg [25]. A klinikus számára, ha kérdéses, a PMR diagnózis felállításában az UH-vizsgálat során észlelt váll- és csípőgyulladás mindenképpen értékes segítséget jelent (4. és 5. ábra).

A korai diagnosztika modern képalkotója, a fluoro18-deoxiglükóz-pozitronemissziós tomográfia (FDGPET) elsősorban nagyérvasculitis megjelenítésére szolgál, de a polymyalgiás gyulladást is korán és jól jelzi, fokozott metabolikus aktivitás figyelhető meg a váll (subacromialis bursitis, biceps tenosynovitis) (94\%), a csípő (trochanterbursitis) $(89 \%)$ és a gerinc (interspinosus bursitis) (51\%) vetületében (6. ábra). Az FDG-PET nagyfokban szenzitív, de kevésbé specifikus, igen költséges eljárás, ezért gyakorlati alkalmazása az atípusos, glükokortikoidra nem reagáló esetekben indokolt. Alacsony térbeli felbontása miatt $\mathrm{CT} / \mathrm{MR}$ angiográfia egészítheti ki [26].

A modern képalkotók (UH/MR/PET) jelentős szerepet játszanak a klinikailag gyanús PMR differenciáldiagnózisában és a betegség monitorozásában is.

\section{Laboratóriumi vizsgálatok}

A PMR az egész szervezetet érintő gyulladásos megbetegedés, a nagyfokú szisztémás gyulladást a laboratórium jól jelzi, gyorsult We- és/vagy emelkedett CRP-érték a diagnózishoz szinte elengedhetetlen. Kivételesen, az esetek 7-22\%-ában, a PMR normális We-értékkel indul [27]. A CRP, mint akutfázis-fehérje, érzékenyebb paraméter, amely a betegség aktivitását jobban jelzi, s ma már

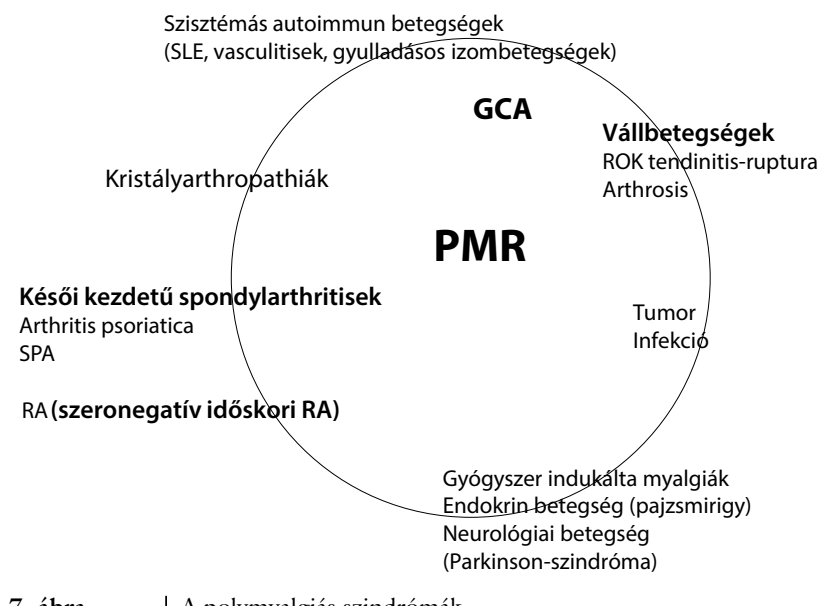

7. ábra |A polymyalgiás szindrómák 
ennek meghatározása is a napi gyakorlat része. A polymyalgiás gyulladás legmegfelelőbb indikátora az IL6-szint-mérés lenne, a gyulladás mértékével a legerősebb asszociációt mutatja, de mérése drága laboratóriumi eljárást igényel, rutinszerüen ma (még?) nem alkalmazzák [16]. A szisztémás gyulladást egyéb akutfázis-fehérjék emelkedése (például fibrinogén, ferritin) és thrombocytosis, anaemia is jelzi. Enyhén emelkedettek lehetnek a májenzimek, a transzaminázok és az alkalikus foszfatáz.

A PMR-nek specifikus laboratóriumi tünete nincs, autoantitest-asszociáció sem ismert. Negatív az RF és az aCCP is. Az aCCP-pozitivitás a valódi PMR-t nagy valószínűséggel kizárja, polymyalgiás kezdetű időskori RA mellett szól [28]. Az aCl jelenléte vascularis komponensre utal [4].

A gyulladásos paraméterek (We/CRP) a betegség aktivitásának monitorozására is alkalmasak, lege artis GCterápia mellett általában pár nap-egy hét alatt normalizálódnak, a remissziót jelzik. Relapsusban emelkedésük előre jelezheti azt, klinikai tünetek hiányában azonban nem feltétlenül jelenti a betegség fellángolását.

\section{Diagnózis - kritériumrendszerek}

A PMR-nek patognosztikus tünete nincs, a diagnózis felállítása a jellegzetes kezdeti klinikai tünetek alapján történik, megerősítésül a GC-terápiára adott közismerten jó terápiás válasz szolgált. Az 1980-as években a téma elismert szakértői saját megfigyeléseik, tapasztalatuk alapján diagnosztikus kritériumrendszereket hoztak létre [2931].

Az 1990-es és 2000-es évek tudományos eredményei és klinikai evidenciái új kritériumok kimunkálását tették szükségessé. Az ACR és az EULAR reumatársaságok PMR-munkacsoportja (magyar résztvevőkkel) hosszú munkafolyamat eredményeként 2012-ben, a betegség történetében először, nemzetközileg standardizált és validált klasszifikációs kritériumrendszert dolgozott ki [8]. Az új és a régi kritériumrendszereket közös táblázatban foglaltuk össze (3. táblázat).

Az új kritériumrendszer elsődlegesen a PMR klasszifikációjára, az egyéb polymyalgiás szindrómák elkülönítésére szolgál, de a mindennapi gyakorlatban diagnosztikus segítségként is alkalmazható. Klinikai gyógyszervizsgálatokhoz szükséges homogén betegcsoportok kialakítását is lehetővé teszi.

$\mathrm{Az}$ ACR/EULAR kritériumok is a kezdeti klinikai tüneteken alapulnak. A klasszifikációhoz 3 alapkritérium (legalább 50 éves beteg, újonnan kezdődött kétoldali vállfájdalommal, kórosan emelkedett laboratóriumi We/ CRP értékkel) teljesítése kötelező. Ehhez további klinikai, illetve opcionális UH-kritériumok társulnak, klasszifikációs értékük szerint különböző pontértékkel (reggeli ízületi merevség [RIM] $>45$ perc -2 pont, csípófájdalom vagy -kötöttség - 1 pont, normális $\mathrm{RF} / \mathrm{aCCP}-2$ pont, perifériás ízületi érintettség hiánya - 1 pont, UHkritériumok - 1-1 pont). A PMR klasszifikációjához a kötelező alapkritériumok mellett a klinikai kritériumokból legalább 4, az UH-kritériumok hozzáadásával legalább 5 pont társulása szükséges. A pontozásos algoritmust a 4. táblázat mutatja.

A PMR klasszifikációs kritériumok szenzitivitása 68\%, specificitása 78\%. A degeneratív vállbetegségek elkülönítésében a specificitás magasabb $(88 \%)$, RA esetén alacsonyabb (65\%), a specificitást az UH-kritériumok növelik $(81 \%)$, degeneratív vállbetegség esetén $89 \%$, RA esetén 70\%. Legújabb szakirodalmi hivatkozások az ACR/ EULAR kritériumok magas specificitását erôsítik meg saját beteganyagon [32], gyakorlati alkalmazhatóságukhoz azonban még nincs elegendő tapasztalat.

\section{Differenciáldiagnózis}

A PMR differenciáldiagnosztikáját a kézikönyvek részletesen tárgyalják, a szóba jövő betegségeket és azok elkülönítő jellegzetességeit az 5. táblázatban foglaltuk össze, a polymyalgiás szindrómákat kördiagramon vázoljuk (7. ábra) $[8,33]$.

A PMR-nek sem klinikai, sem laboratóriumi specifikus tünete nincs. A polymyalgiás tünetcsoport sem specifikus, a perifériás ízületi érintettség tovább bonyolítja a helyzetet. Paraneoplasiát, infekciót mindig ki kell zárni, elófordul, hogy belgyógyászati vagy neurológiai betegség jelenik meg hasonló formában. Ismeretlen eredetú láz (FUO) egy részében is PMR igazolható [34]. Sok esetben társul GCA, ilyenkor annak ischaemiás differenciáldiagnosztikáját is szem előtt kell tartani [4]. Atípusos esetben ismételt kivizsgálásra lehet szükség. A gyanújeleket a 6. táblázatban foglaltuk össze [35].

Polymyalgiás szindróma képében kezdődhet számos más gyulladásos és nem gyulladásos időskori mozgásszervi megbetegedés is, a degeneratív vállbetegségek mellett az időskorban kezdődő RA és a késői kezdetű spondylarthritisek ( $\mathrm{ppA}$ ) emelendők ki. Elkülönítésük sokszor reumatológusok számára is komoly nehézséget okoz [36].

\section{PMR és arthritis}

Ismert az időskori gyulladásos arthritisek és a PMR közötti overlap (8. ábra). Időskori RA gyakran kezdődik „polymyalgiásan”, akut nagy gyulladással, kétoldali vállérintettséggel (64\% vs. RA vállérintettséggel 38\%) [37]. A PMR-esetek 39-45\%-ában figyeltek meg distalis ízületi érintettséget $[8,19,20]$. A PMR distalis megjelenése változatos (oligoarthritis, tenosynovitis, carpal tunnel, RS3PE-szindróma), míg RA-ban, természetszerúen időskori kezdettel is, dominál a perifériás (szimmetrikus) synovitis és az RF/aCCP pozitivitás. PMR-ben aCCPpozitivitást kimutatni ez ideig nem tudtak [13, 28]. Késői kezdetû $\mathrm{SpA}$ is indulhat tôízületi érintettséggel, ugyanakkor perifériás tünetei, az aszimmetrikus oligoarthritis és a jellegzetes RS3PE-szindróma szintén átfedést jelentenek a PMR-rel [36, 38]. 


\begin{tabular}{|c|c|}
\hline Diagnózis & Klinikai jellemzók \\
\hline \multicolumn{2}{|l|}{ Gyulladásos megbetegedések } \\
\hline Polymyalgia rheumatica & $\begin{array}{l}\text { Életkor> } 50 \text { év, domináló } \\
\text { proximalis vállövi és medenceövi } \\
\text { tünetek, szimmetrikus, } \\
\text { rtg: non-erozív izületi betegség }\end{array}$ \\
\hline Rheumatoid arthritis & $\begin{array}{l}\text { Főleg distalis ízületi tünetek, } \\
\text { RF/aCCP pozitivitás, } \\
\text { rtg: erozív ízületi betegség }\end{array}$ \\
\hline $\begin{array}{l}\text { Késői kezdetű spondylarthritis } \\
\text { (SPA, PsA stb.) }\end{array}$ & $\begin{array}{l}\text { Domináló derékfájdalom és } \\
\text { kötöttség, lehetnek distalis } \\
\text { nagyízületi tünetek, } \\
\text { rtg: gerinc ankylosis, psoriasis }\end{array}$ \\
\hline RS3PE* szindróma & Perifériás kéz és láb oedema \\
\hline $\begin{array}{l}\text { SLE, scleroderma, Sjögren } \\
\text { szindróma, vasculitis }\end{array}$ & $\begin{array}{l}\text { Fáradékonyság, gyengeség, } \\
\text { multiszisztémás betegség, } \\
\text { ANF és ANCA jelenléte }\end{array}$ \\
\hline DM-PM & $\begin{array}{l}\text { Proximalis izomgyengeség, } \\
\text { bőrpír, CK emelkedett }\end{array}$ \\
\hline \multicolumn{2}{|l|}{ Nem gyulladásos betegségek } \\
\hline Arthrosis, spondylosis & $\begin{array}{l}\text { Váll, nyak és csípő ízületi } \\
\text { fájdalom, sántítás, } \\
\text { rtg: degeneratív elváltozások }\end{array}$ \\
\hline $\begin{array}{l}\text { Rotator köpeny betegség, } \\
\text { adhezív capsulitis }\end{array}$ & $\begin{array}{l}\text { Periartikuláris fájdalom, } \\
\text { mozgáskorlátozottság, } \\
\text { UH és MR jellegzetes bursalis/ } \\
\text { synovialis gyulladást mutathat }\end{array}$ \\
\hline $\begin{array}{l}\text { Infekciók, osteomyelitis, } \\
\text { bakteriális endocarditis, tbc }\end{array}$ & $\begin{array}{l}\text { Láz, fogyás, szívzörej, mély } \\
\text { lágyrész- és csontfájdalom, } \\
\text { mikroszkópos hematuria }\end{array}$ \\
\hline Tumorok & Fogyás, fáradékonyság, \\
\hline $\begin{array}{l}\text { lymphoma, leukaemia, myeloma, } \\
\text { amyloidosis, occult solid tumor }\end{array}$ & $\begin{array}{l}\text { kivizsgálás a tünetek, a nem és az } \\
\text { életkor alapján }\end{array}$ \\
\hline Parkinsonizmus & $\begin{array}{l}\text { Merevség, figiditás, csoszogó } \\
\text { járás, fokozatos kezdet }\end{array}$ \\
\hline $\begin{array}{l}\text { Krónikus fájdalom szindrómák, } \\
\text { fibromyalgia, depresszió }\end{array}$ & $\begin{array}{l}\text { Fáradékonyság, hosszantartó } \\
\text { fájdalom, „tender pontok”, } \\
\text { lehangoltság, az általános } \\
\text { érdeklődés hiánya }\end{array}$ \\
\hline $\begin{array}{l}\text { Endokrin és csontanyagcsere } \\
\text { betegségek: } \\
\text { hyper/hypothyreosis, } \\
\text { hyper/hypoparathyreosis } \\
\text { D-hypovitaminosis, osteomalacia } \\
\text { álköszvény Ca-pirofoszfát- } \\
\text { lerakódással }\end{array}$ & $\begin{array}{l}\text { Csontfájdalom, fáradékonyság, } \\
\text { kóros PTH, Ca, P, D-vitamin, } \\
\text { TSH }\end{array}$ \\
\hline
\end{tabular}

* Múló seronegatív szimmetrikus sínovitis ujjbenyomatot tartó oedemával

\section{PMR és arteritis}

PMR 16-21\%-ban társul klinikailag manifeszt GCA/ TA-val, ugyanakkor a GCA 40-60\%-ában van polymyalgiás tünetcsoport. Izolált PMR (PMR óriássejtes arteritis klinikai tünetei nélkül) 15-20\%-ában szubklinikus TA zajlik, klinikai tünet nincs, de a temporalisartéria-biopszia (TAB) pozitív. A TA UH-vizsgálatával észlelt halo jel (az érlumen körül az érfal echószegényen [sötét], körkörösen, egyenletesen megvastagodott) nagy segítség a GCA diagnózisában, de a szövettant nem helyette-

\section{6. táblázat | „Gyanús” PMR}

\section{Fiatalabb életkor}

Férfi nem

Krónikus kezdet

Vállérintettség hiánya

Perifériás arthritis

Gerincérintettség

Súlyos általános tünetek

We/CRP extrém magas vagy normális

A korai, gyors GC-válasz elmarad

síti [39]. Izolált PMR 31\%-ában FDG-PET vizsgálattal szubklinikus nagyér-vasculitist lehet kimutatni, leggyakoribb lokalizáció az aorta és az arteria subclavia [40].

\section{Kezelés}

A PMR kezelésében még ma is a GC az egyetlen hatásos szer. Számos betegségmódosító terápiával, klasszikus bázisszerekkel, újabban TNF-gátlókkal, biológiai szerekkel történtek próbálkozások, de egyelöre nem sok sikerrel. Az IL-6-gátlás új reményeket kelthet [4].

A GC-terápia egyénre szabott, a GC-t olyan adagolásban kell adni, hogy a beteg meggyógyuljon, ugyanakkor az egyébként is veszélyeztetett idős korosztály a GC ismert mellékhatásait elkerülje. Egységesen elfogadott terápiás séma nincs. Társuló GCA hiányában szájon át napi 10-20 mg prednizolonekvivalens dózissal (PED) kezdünk, amelyet a beteg klinikai állapotától, a betegség gyulladásos aktivitásától (a We/CRP értéktól) függően lassan, fokozatosan csökkentünk. Az ACR/EULAR klasszifikációs vizsgálatban alkalmazott terápiás protokollt példaként ismertetjük (9. ábra): $15 \mathrm{mg} /$ nap kezdő dózis, 2 hetente 2,5 mg/nap PED-csökkentés $10 \mathrm{mg} /$ nap dózisig, majd havonta napi $1-2,5 \mathrm{mg} / \mathrm{nap}$ PEDcsökkentés a GC teljes elhagyásáig, a terápia befejezéséig [8].

Megfelelő adagolás mellett a PMR rendszerint 1-1,5 éven belül gyógyul. A szükségesnél nagyobb kezdő dózis vagy a dózis túl gyors csökkentése relapsus veszélyével jár. „Kis dózisú” GC-re a betegség általában gyorsan és jól reagál, a tünetek néhány napon belül csökkennek, rendszerint el is múlnak, a We/CRP érték normalizálódik. (Hagyományosan kis dózisú GC-nek nevezzük a 15-20 mg/nap GC-t, a GCA-ban szükséges nagy dózisú GC [40-60 mg/nap] viszonylatában.) Ez a gyors GCreakció az úgynevezett Dixon-próba, ami a diagnózist megerősíti, az ismert régi kritériumrendszerek része. $\mathrm{Ma}$ úgy tûnik, hogy ez a PMR-t általánosságban jellemző, szinte tabunak számító, korai gyors GC-válasz az esetek egy részében elmarad, a 2012-es klasszifikációs kritériumok között már nem szerepel. A jó GC-válasz elmara- 


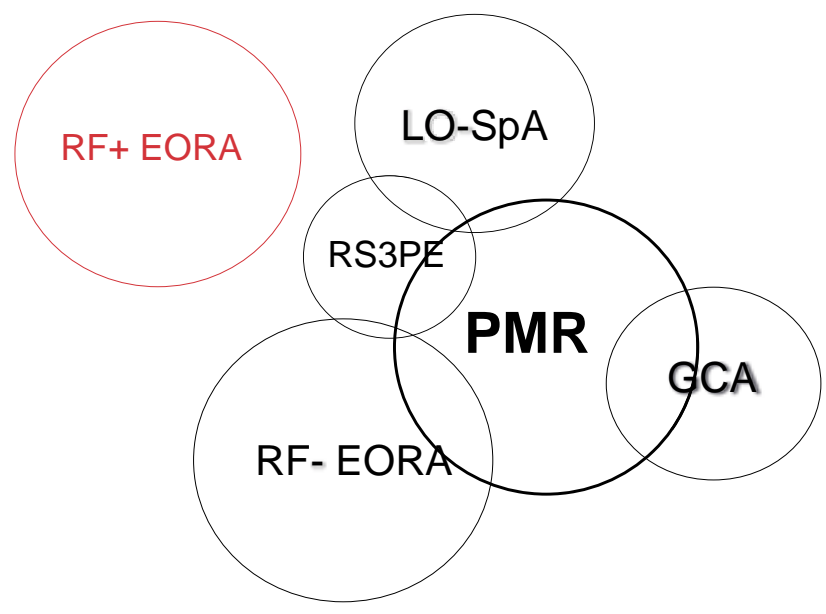

8. ábra

| A PMR és arthritises/arteritises átfedései

dása, bár gyanút kelt, de a PMR diagnózisát nem zárja ki.

Az utóbbi években kezd kikristályosodni a „GC-rezisztens PMR" fogalma is, lege artis GC-adagolás ellenére a betegek harmadában-felében krónikus, relapsusokkal tarkított lefolyást figyelhetünk meg [19]. Relapsusra, krónikus lefolyásra hajlamosítanak, ha a kezdeti gyulladás nagyfokú (We/CRP), perifériás arthritis társul és a beteg neme nő.

A rezisztens betegek GC-terápiára szorulnak hosszú távon. A hosszú távú GC-terápia mellékhatásai (osteoporosis, osteoporoticus fractura, hypertonia, hyperlipidaemia, diabetes stb.) jól ismertek. A GC-mellékhatások kezelése és megelőzése a polymyalgiás betegek gondozásának egyik legfontosabb feladata. Gyakoriak, legalább egy mellékhatás az esetek 65\%-ában fordul elő, a GC kumulatív dózisa mellett az idős életkor és a női nem egymástól független rizikófaktorok.

A GC-dózis csökkentése céljából különböző betegségmódosító terápiás próbálkozások történtek, egyelőre csekély sikerrel. A klasszikus betegségmódosító (DMARD) szerek közül alkalmazták már az azathioprint, a methotrexatot (MTX), és egyesek a leflunomidot javasolták. Hazánkban a pécsi klinika cyclophosphamidkezelésről számolt be kisszámú beteganyagon [41, 42]. Olasz multicentrikus, prospektív és saját retrospektív vizsgálatunkban az MTX kombinált kezelés heti 10 mg adagolásban hosszú távon nem eredményezett szignifikáns különbséget a GC-monoterápiával szemben; a relapsusok számát, a GC kumulatív dózisát és a GC-mellékhatásokat vizsgáltuk. További nagyszámú randomizált kontrollált vizsgálatra (RCT) lenne szükség az MTX nagyobb dózisú (15 mg/hét) alkalmazásával, relapsusokkal járó/krónikus lefolyású PMR-ben [43, 44].

Újabban világszerte biológiai terápiákkal próbálkoznak. A TNF-blokkoló szerek hatásosak lehetnek a krónikus, hosszú távú GC-terápiát igénylő esetekben - az etanercept és az infliximab is GC-mentes remissziót eredményezett -, de hatástalanok az újonnan diagnoszti-

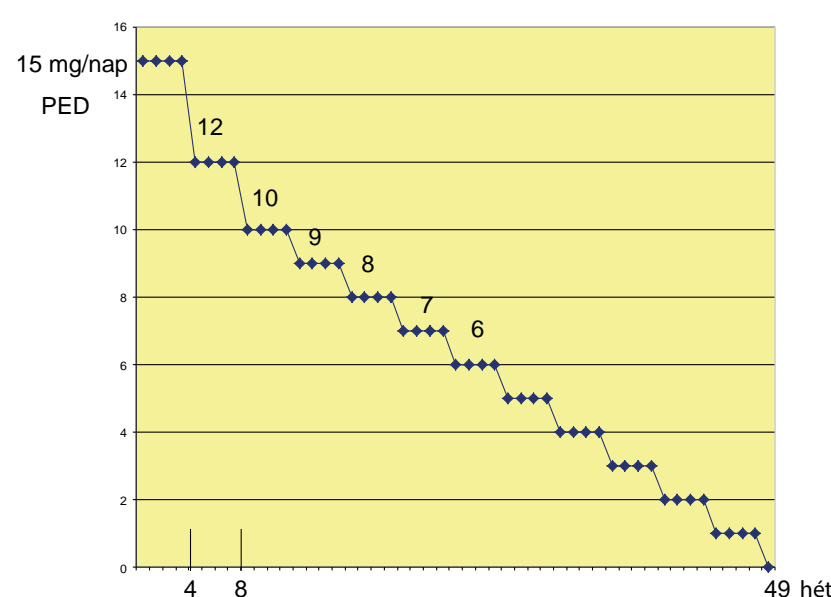

9. ábra | GC-terápiás protokoll (ACR/EULAR 2012)

zált PMR-ben [45]. A sIL-6R-ellenes tocilizumab természeténél fogva (az IL-6 kulcsszerepet játszik a PMR patogenezisében) hatékony és biztonságos lehet az újonnan diagnosztizált GC-naiv betegek kezelésében is. Ennek igazolásához azonban a tájékozódó jellegú nyílt vizsgálatok után szintén nagyszámú beteganyagon végzett prospektív vizsgálatok szükségesek [46]. További lehetőségként a T-sejt-kostimulációt módosító abatacept alkalmazását vetik fel.

\section{GC-kronoterápia}

A GC-terápia haszon-kockázat hányadosának javítása, a dózis csökkenthetősége és kevesebb mellékhatás céljából egy új GC-gyógyszerformát fejlesztettek ki (Mundipharma). A késleltetett hatóanyag-kibocsátású prednizolon a HPA-tengely és a proinflammatorikus citokin-termelés PMR-ben észlelt cirkadián ritmusához alkalmazkodik. Esti bevételét követően a prednizolon kibocsátása késleltetetten 4-6 óra múlva kezdődik, így az a proinflammatorikus citokinek éjszakai-hajnaltáji emelkedését akadályozza meg, a reggeli gyulladásos tünetek már ki sem alakulnak [47]. A Lodotrát RA-ban külföldön törzskönyvezték, PMR-ben törzskönyvezése elmaradt, az ehhez szükséges RCT alapjául szolgáló protokoll újratervezése folyamatban van.

Az ACR/EULAR PMR munkacsoportja a 2012-es klasszifikációs kritériumok után a PMR kezelési-gondozási alapelveinek kidolgozásába kezdett. Szakirodalmazás, majd az egyéni vélemények egyeztetése alapján a következő terápiás ajánlás született [48]:

PMR kezelésére a közepes dózisú (7,5-30 mg/nap) GC javasolt, a lehető legkisebb kezdő dózis 12,5-25 $\mathrm{mg}$ /nap között mozog. Nagy dózisú (30-100 mg/nap) GC alkalmazása szigorúan ellenjavallt, ez egyéb gyulladásos betegségekben is hatásos lehet, s így elfedheti a helyes diagnózist. GC parenteralis (im.) adagolása jöhet szóba a PMR-rizikócsoportokban. Szintén a rizikócsoportokban, ahol a PMR melletti társbetegségek és azok 
terápiája a GC-mellékhatásokra fokozott kockázatot jelent, MTX indítása a GC mellett megfelelő dózisban már a betegség indulásakor javasolt. NSAID-ot nem érdemes adni, mert hatástalan. A biológiai terápiák közül az antiTNF - mindent egybevetve - nem javasolt. IL-6-ellenes szerről még kevés adat áll rendelkezésre. Kérdés továbbra is, hogy a GC-dózist milyen ütemben csökkentsük, s a napi dózist egyszeri vagy osztott adagolásban adjuk.

\section{Remisszió, relapsus}

A PMR lefolyása során gyakoriak a relapsusok. Relapsusra utal, ha a klinikai tünetek fellángolnak és a laboratóriumi gyulladásos paraméterek (We/CRP) emelkednek. A GC adagját ilyenkor a relapsus előtti még hatásos dózisra emeljük vissza, ismételt remisszió céljából.

A relapsust, a remissziót a betegség aktivitása határozza meg. A PMR aktivitását újabban, az RA-hoz hasonlóan, összetett pontszámmal, a Leeb-féle PMR-aktivitási score-ral (PMR-AS) mérjük [49]. A PMR-AS összetevői a CRP, a beteg fájdalma és az orvos általános véleménye vizuális analóg skálán (VAS) jelölve, a reggeli ízületi merevség és a karemelés mértéke. Az RA-val ellentétben a PMR-AS alkalmazása még nem vált a mindennapi gyakorlat részévé. Az ACR/EULAR égisze alatt a fenti fogalmak standardizálása is folyamatban van [50].

\section{Gondozás}

A PMR diagnózis felállítása és kezelése reumatológus szakorvos feladata. A betegség felismerésében, differenciálásában a családorvos szerepe elengedhetetlen, hiszen a beteget a területen először többnyire ő észleli. A polymyalgiás beteg nagybeteg benyomását kelti, így joggal merülhet fel malignus folyamat vagy infekció lehetősége. A típusos polymyalgiás klinikumot ismerve azonban az idős szervezetet terhelő részletes kivizsgálás feleslegessé válik. A családorvos együttmúködése a beteg ellátásában is rendkívül fontos, miszerint a reumatológus által megkezdett és vezérelt lege artis GC-terápiát nem akarja idő előtt leállítani, a GC hosszú távú adásának szükségességét a területen is megerősíti, az esetleges mellékhatásokat pedig, betegközelben lévén, szükség esetén gyógyszeresen ellátja.

A családorvos feladata az is, hogy esetleges társuló arteritis súlyos szövődményeire gondol, ha a polymyalgiás betegben fejfájás, látászavar, stroke vagy angina pectoris lép fel, és a beteget sürgősséggel kórházba utalja.

A polymyalgiás tünetek heterogenitása folytán előfordulhat, hogy a beteg a társszakmák képviselőinél jelentkezik először, ilyenkor a PMR-gyanú az ortopéd, traumatológus, szemész, fülész, angiológus, belgyógyász kollégában merül fel. A betegség ismerete tehát valamennyiünk számára nélkülözhetetlen.
Anyagi támogatás: A közlemény megírása anyagi támogatásban nem részesült.

Szerzői munkamegosztás: S. Zs.: Az irodalom gyưjtése és feldolgozása, a kézirat elkészítése. P. Gy.: Témaválasztás, a kézirat átnézése és jóváhagyása. A cikk végleges változatát mindkét szerző elolvasta és jóváhagyta.

Érdekeltségek: A szerzőknek nincsenek érdekeltségeik.

\section{Irodalom}

[1] Salvarani, C., Cantini, F., Boiardi, L., et al.: Polymyalgia rheumatica. Best Pract. Res. Clin. Rheumatol., 2004, 18(5), 705722.

[2] Schmidt, Zs.: Polymyalgia rheumatica. [Polymyalgia rheumatica.] Családorvosi Fórum, 2006, 7(4), 13-17. [Hungarian]

[3] Salvarani, C., Cantini, F., Hunder, G. G.: Polymyalgia rheumatica and giant-cell arteritis. Lancet, 2008, 372(9634), 234-245.

[4] Salvarani, C., Rueda, J., Gonzalez-Gay, M. A.: Polymyalgia rheumatica and giant cell arteritis. In: Bijlsma, J. W. (ed.): EULAR Textbook on Rheumatic Diseases. 1st ed. BMJ Publishing Group Ltd and EULAR, London, 2012, Chapter 28.

[5] Matteson, E. L.: Polymyalgia rheumatica and giant cell arteritis: past, present and future. Rheumatology (Oxford), 2014, 53(Suppl. 2), il-il2.

[6] Hunder, G. G.: The early history of giant cell arteritis and polymyalgia rheumatica: first descriptions to 1970 . Mayo Clin. Proc., 2006, 81(8), 1071-1083.

[7] Hodinka, L., Temesvári, P., Bozsóky, S.: Polymyalgia rheumatica and generalized giant cell arteritis. [Polymyalgia rheumatica és generalizált óriássejtes arteritis.] Magyar Belorvosi Archívum, 1978, 31, 153-159. [Hungarian]

[8] Dasgupta, B., Cimmino, M. A., Maradit-Kremers, H., et al.: 2012 provisional classification criteria for polymyalgia rheumatica. A European League Against Rheumatism/American College of Rheumatology collaborative initiative. Ann. Rheum. Dis., 2012, 71(4), 484-492.

[9] Cimmino, M. A., Zaccaria, A.: Epidemiology of polymyalgia rheumatica. Clin. Exp. Rheumatol., 2000, 18(4 Suppl. 20), S9S11.

[10] Dasgupta, B., Kremers, H. M., Mattesson, E. L.: Disease burden, quality of life and other measures of polymyalgia rheumatica. In: Preedy, V. R., Watson, R. R. (eds.): Handbook of Disease Burden and Quality of Life Measures. Springer Science, New York, 2010.

[11] Guerne, P. A., Salvi, M., Seitz, M., et al.: Molecular analysis of HLA-DR polymorphism in polymyalgia rheumatica. Swiss Group for Research on HLA in Polymyalgia Rheumatica. J. Rheumatol., 1997, 24(4), 671-676.

[12] Poór, G., Nagy, Z. B., Schmidt, Z., et al.: Genetic background of anticyclic citrullinated peptide autoantibody production in Hungarian patients with rheumatoid arthritis. Ann. N.Y. Acad. Sci., 2007, 1110, 23-32.

[13] Schmidt, Z., Blazsek, A., Brózik, M., et al.: Lack of anti-cyclic citrullinated antibody and HLA DRB1*0401 might partly explain the benign synovitis in polymyalgia rheumatica. Ann. Rheum. Dis., 2006, 65(SII), 71.

[14] Duhaut, P., Bosshard, S., Dumontet, C.: Giant cell arteritis and polymyalgia rheumatica: role of viral infections. Clin. Exp. Rheumatol., 2000, $18(4$ Suppl. 20), S22-S23.

[15] Alvarez-Rodriguez, L., Lopez-Hoyos, M., Mata, C., et al.: Circulating cytokines in active polymyalgia rheumatica. Ann. Rheum. Dis., 2010, 69(1), 263-269.

[16] Salvarani, C., Cantini, F., Niccoli, L., et al.: Acute-phase reactants and the risk of relapse/recurrence in polymyalgia rheumat- 
ica: a prospective followup study. Arthritis Rheum., 2005, 53(1), 33-38.

[17] Straub, R. H., Cutolo, M.: Further evidence for insufficient hypothalamic-pituitary-glandular axes in polymyalgia rheumatica. J. Rheumatol., 2006, 33(7), 1219-1223.

[18] Hunder, G. G.: Clinical features of GCA/PMR. Clin. Exp. Rheumatol., 2000, 18(4 Suppl. 20), S6-S8.

[19] Salvarani, C., Cantini, F., Macchioni, P., et al.: Distal musculoskeletal manifestations in polymyalgia rheumatica: a prospective follow-up study. Arthritis Rheum., 1998, 41(7), 1221-1226.

[20] Schmidt, Zs., Brózik, M., Kaposi, N. P., et al.: Initial symptoms of polymyalgia rheumatica. [A polymyalgia rheumatica kezdeti tünetei.] Magy. Reumatol., 2010, 51(3), 234. [Hungarian]

[21] Salvarani, C., Cantini, F., Olivieri, I., et al.: Polymyalgia rheumatica: A disorder of extraarticular synovial structures? J. Rheumatol., 1999, 26(3), 517-521.

[22] Pavlica, P., Barozzi, L., Salvarani, C., et al.: Magnetic resonance imaging in the diagnosis of PMR. Clin. Exp. Rheumatol., 2000 18(4 Suppl. 20), S38-S39.

[23] Cantini, F., Salvarani, C., Olivieri, I., et al.: Shoulder ultrasonography in the diagnosis of polymyalgia rheumatica: a case control study. J. Rheumatol., 2001, 28(5), 1049-1055.

[24] Schmidt, W. A., Cimmino, M. A., Mandl, P., et al.: Utility of ultrasound in the diagnostic assessment of shoulder pain in polymyalgia rheumatica: Results from an international, prospective, multi-center longitudinal study. ACR-EULAR Study Group for Development of Classification Criteria for PMR. Arthritis Rheum., 2010, 62(Suppl. 10), 682

[25] Mackie, S., Koduri, G., Hill, C. L., et al.: The use of imaging in the diagnosis of polymyalgia rheumatica: Systematic literature review and meta-analysis. Arthritis Rheum., 2014, 66(Suppl. 10), 1211

[26] Blockmans, D., De Ceuninck, L., Vanderschueren, S., et al.: Repetitive 18-fluorodeoxyglucose positron emission tomography in isolated polymyalgia rheumatica: a prospective study in $35 \mathrm{pa}-$ tients. Rheumatology (Oxford), 2007, 46(4), 672-677.

[27] Hazleman, B.: Laboratory investigations useful in the evaluation of polymyalgia rheumatica and giant cell arteritis. Clin. Exp. Rheumatol., 2000, 18(4 Suppl. 20), S29-S31.

[28] Lopez-Hoyos, M., Ruiz de Alegria, C., Blanco, R., et al.: Clinical utility of anti-CCP antibodies in the differential diagnosis of elderly-onset rheumatoid arthritis and polymyalgia rheumatica Rheumatology, 2004, 43(5), 655-657.

[29] Healey, L. A.: Long term follow up of polymyalgia rheumatica: evidence for synovitis. Semin. Arthritis Rheum., 1984, 13(4), 322-328

[30] Hunder, G. G.: Diagnostic criteria for polymyalgia rheumatica. Ann. Intern. Med., 1982, 97, 24-27.

[31] Bird, H. A., Esselinckx, W., Dixon, A. S., et al.: An evaluation of criteria for polymyalgia rheumatica. Ann. Rheum. Dis., 1979, $38(5), 434-439$

[32] Macchioni, P., Boiardi, L., Catanoso, M., et al.: Performance of the new 2012 EULAR/ACR classification criteria for polymyalgia rheumatica: comparison with the previous criteria in a singlecentre study. Ann. Rheum. Dis., 2014, 73(6), 1190-1193.

[33] Michet, C. J., Matteson, E. L.: Polymyalgia rheumatica. BMJ, 2008, 336(7647), 765-769.

[34] Naito, T., Mizooka, M., Mitsumoto, F., et al.: Diagnostic workup for fever of unknown origin: a multicenter collaborative retrospective study. BMJ, 2013, 3(12), e003971.

[35] Dasgupta, B., et al.: Polymyalgia: What is it? In: 2014 ACR/ EULAR guidelines for treatment and management of polymyalgia rheumatica. ACR/ARHP Annual Meeting, 2014, Boston.
[36] Olivieri, I., Pipitone, N., D'Angelo, S., et al.: Late-onset rheumatoid arthritis and late-onset spondyloarthritis. Clin. Exp. Rheumatol., 2009, 27(4 Suppl. 55), S139-S145.

[37] Caporali, R., Montecucco, C., Epis, O., et al.: Presenting features of polymyalgia rheumatica (PMR) and rheumatoid arthritis with PMR-like onset: a prospective study. Ann. Rheum. Dis., 2001, 60(11), 1021-1024.

[38] Cantini, F., Salvarani, C., Olivieri, I., et al.: Remitting seronegative symmetric synovitis with pitting edema (RS3PE) syndrome: a prospective follow-up and magnetic resonance imaging study. Ann. Rheum. Dis., 1999, 58(4), 230-236.

[39] Schmidt, W. A., Kraft, H. E., Vorpahl, K., et al.: Color duplex ultrasonography in the diagnosis of temporal arteritis. N. Engl. J. Med., 1997, 337(19), 1336-1342.

[40] Yamashita, H., Kubota, K., Takahashi, ., et al.: Whole-body fluorodeoxyglucose positron emission tomography/computed tomography in patients with active polymyalgia rheumatica: evidence for distinctive bursitis and large-vessel vasculitis. Mod. Rheumatol., 2012, 22(5), 705-711.

[41] Diamantopoulos, A. P., Dasgupta, B.: A double-blind, randomized, placebo-controlled pilot study of leflunomide in polymyalgia rheumatica. Rheumatology (Oxford), 2014, 53(Suppl. 2), i8.

[42] Kiss, Cs. Gy., Radics, J., Czirják, L.: Cyclophosphamide infusion treatment of polymyalgia rheumatica not responding to conventional therapy. [Hagyományos terápiára nem reagáló polymyalgia rheumatica kezelése cyclophosphamid infúzióval.] Magy. Reumatol., 2008, 49(3), 145. [Hungarian]

[43] Cimmino, M. A., Salvarani, C., Macchioni, P., et al.: Long-term follow-up of polymyalgia rheumatica patients treated with methotrexate and steroids. Clin. Exp. Rheumatol., 2008, 26(3), 395400.

[44] Schmidt, Zs., Hittner, Gy., Poór, Gy.: Long-term treatment of polymyalgia rheumatica. [A polymyalgia rheumatica hosszú távú kezelése.] Magy. Reumatol., 2010, 51(4), 274-277. [Hungarian]

[45] Salvarani, C., Hunder, G. G.: Tumor necrosis factor blocking agents in polymyalgia rheumatica and giant cell arteritis. Ann. Intern. Med., 2008, 148(2), 167-168.

[46] Macchioni, P., Boiardi, L., Catanoso, M., et al.: Tocilizumab for polymyalgia rheumatica: report of two cases and review of the literature. Semin. Arthritis Rheum., 2013, 43(1), 113-118.

[47] Spies, C. M., Cutolo, M., Straub, R. H., et al.: Prednisone chronotherapy. Clin. Exp. Rheumatol., 2011, 29(5 Suppl. 68), S42S45.

[48] Matteson, E. L., et al.: Polymyalgia rheumatica: Treatment guidelines and next steps. In: 2014 ACR/EULAR guidelines for treatment and management of polymyalgia rheumatica. ACR/ARHP Annual Meeting, 2014, Boston.

[49] Leeb, B. F., Bird, H. A.: A disease activity score for polymyalgia rheumatica. Ann. Rheum. Dis., 2004, 63, 1279-1283.

[50] Dejaco, C., Duftner, C., Cimmino, M. A., et al.: Definition of remission and relapse in polymyalgia rheumatica: data from a literature search compared with a Delphi-based expert consensus. Ann. Rheum. Dis., 2011, 70(3), 447-453.

(Schmidt Zsuzsa dr., e-mail: med.palace@t-online.hu) 